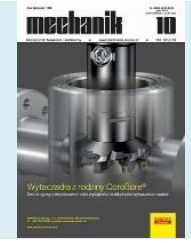

Authors: Jan Burek, Piotr Żurek, Karol Żurawski

Title of article: „Badania symulacyjne siły skrawnia w procesie obróbki frezem baryłkowym” („Simulation testing of cutting force in the process of barrel milling machining")

Mechanik, Vol. 91, No. 10 (2018): pages 901-903

DOI: https://doi.org/10.17814/mechanik.2018.10.158

\title{
Simulation testing of cutting force in the process of barrel milling machining
}

\author{
Badania symulacyjne siły skrawania \\ w procesie obróbki frezem baryłkowym
}

\section{JAN BUREK \\ PIOTR ŻUREK \\ KAROL ŻURAWSKI *}

The paper presents simulation tests of cutting force in the process of barrel milling. The analyses were carried out on concave and convex surfaces with different radii of curvature. KEYWORDS: 5-axis milling, barrel mill, cutting force

In industrial practice, an increase in the use of five-axis milling is observed, especially during the production of components with complex shapes, such as rotors, blades and dies. The machining of such parts is most often carried out in a spherical milling strategy (fig. 1a). It allows you to make any shape, but it is characterized by very low efficiency. That is why new milling designs are being sought, which will enable the increase of the surface machining efficiency.

One of such constructions is a barrel mill with a repeatedly increased radius of the cutting edge shape $r_{n}$ (fig. 1b). This solution contributes to increasing the axial infeed of $b$ (machining path width), and thus - repeatedly increasing the surface machining efficiency. However, the change in the axial infeed results in a significant increase in the crosssection area of the cutting layer and the effective cutting edge length $[1,5,6,8,10]$.

In addition, in the case of a barrel milling cutter, the curvature radius of the machined surface influences the area of the cutting layer (fig. 2). Depending on the sign of curvature ("+" convex, "-" concave) and values, the conditions of contact between the tool and the workpiece change [9].

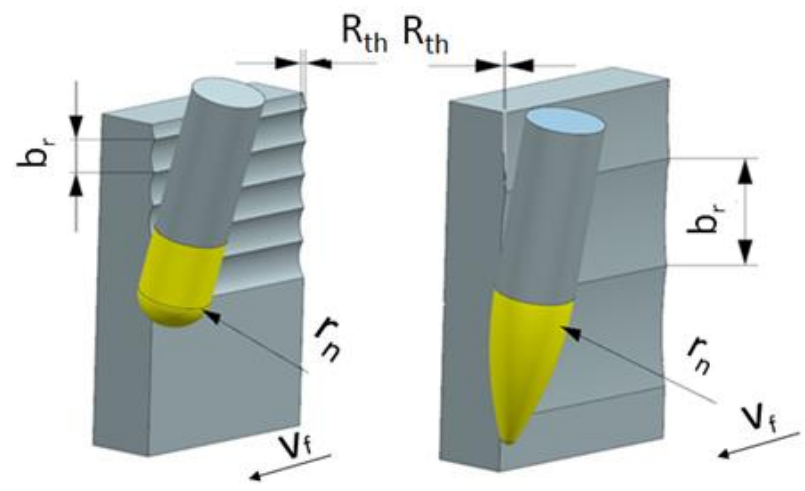

Fig. 1. Five-axis machining: a) ball milling cutter, b) barrel milling cutter [4]

Dr hab. inż. Jan Burek prof. PRz (jburek@prz.edu.pl), mgr inż. Karol Żurawski (zurawski@prz.edu.pl), mgr inż. Piotr Żurek (p_zurek@prz.edu.pl) - Katedra Technik Wytwarzania i Automatyzacji Politechniki Rzeszowskiej

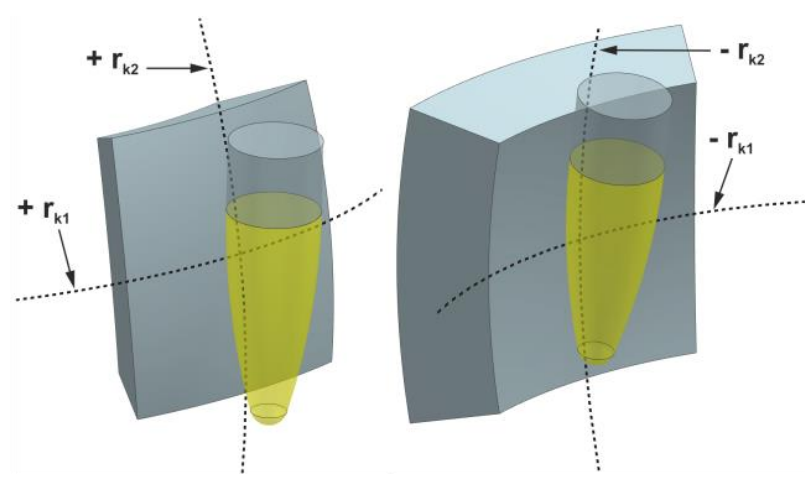

Fig. 2. Radius of curvature of concave and convex surface [4]

The change of these parameters directly affects the values and course of the cutting force components. The cutting force causes elastic deformations of the machine tool - tool workpiece system and affects the shape errors of the workpiece surface. Therefore, its analysis is extremely important in the process of five-axis machining with the use of a barrel milling cutter, especially considering the radius of curvature of the machined surface [9].

The mechanistic model (1) was adopted for the tests, while the simulation analysis was used to determine the length of the cutting edge $S$ and the cross-sectional area of the machined layer $A$. The distribution of the cutting forces for the barrel milling cutter is shown in fig. $3[1,7]$.

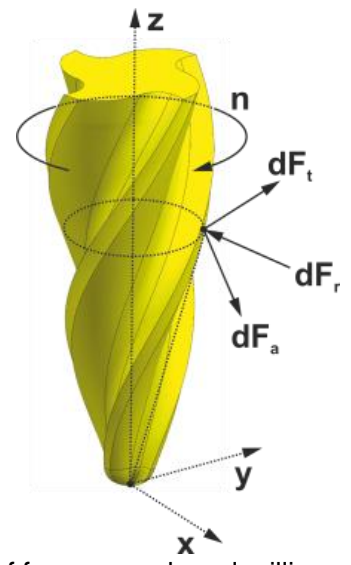

Fig. 3. Distribution of forces on a barrel milling cutter [1] 


$$
\left\{\begin{array}{l}
d F_{\mathrm{t}}=K_{\mathrm{te}} d S+K_{\mathrm{tc}} d A \\
d F_{\mathrm{r}}=K_{\mathrm{re}} d S+K_{\mathrm{rc}} d A \\
d F_{\mathrm{a}}=K_{\mathrm{ae}} d S+K_{\mathrm{ac}} d A
\end{array}\right.
$$

where:

$F_{\mathrm{t}}$ - tangential component of the cutting force,

$F_{\mathrm{r}}$ - radial component of the cutting force,

$F_{\mathrm{a}}$ - axial component of the cutting force,

$S$ - active length of the cutting edge,

$A$ - cross-sectional area of the cutting layer,

$K_{\mathrm{te}}, K_{\mathrm{re}}, K_{\mathrm{ae}}$ - edge proportionality factors affecting the cutting edge, determined experimentally,

$K_{\mathrm{tc}}, K_{\mathrm{rc}}, K_{\mathrm{ac}}$ - proportionality factors related to shear, determined experimentally.

The aim of the research was to determine the courses and values of the components of the cutting force in the machining of concave and convex surfaces with different values of the radius of curvature.

\section{Research methodology}

The values of the cutting force components were determined using Boolean operations carried out between the test model and the tool model. The model assumes a barrel milling cutter with a radius of cutting edge $r_{n}=85 \mathrm{~mm}$. The feed per tooth was $f_{z}=0.2 \mathrm{~mm}$. The test models were surfaces with different radii of curvature (tab. I).

First, test models of the workpiece were prepared in the NX 11 system. Next, the test bodies were imported into the hyperMill system, where they were used to develop machining paths for each model and an intermediate code was generated.

The next step was to model the tool, which was copied in a pattern created based on the previously imported intermediate code. 80 copies per one revolution of the tool were made. Then, the tool models were subtracted from the object model. As a result of this operation, the cross-sectional area of the cutting layer and the length of the active cutting edge were obtained (fig. 4). These parameters (tab. II) were applied in mechanistic formulas allowing to determine the components of the cutting forces occurring in the process [2, $4,11]$.

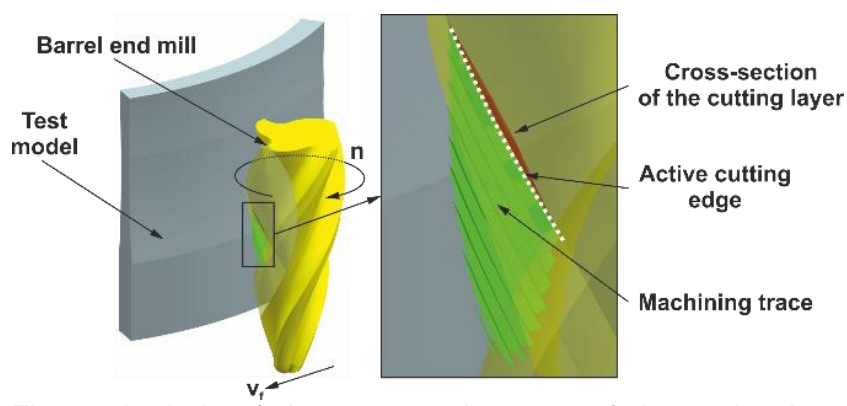

Fig. 4. Analysis of the cross-section area of the cutting layer determined by Boolean operations

TABLE I. Values of radii of curvature of test models

\begin{tabular}{|c|c|c|}
\hline Number & $\boldsymbol{h}_{\mathbf{k} \mathbf{1}}, \mathbf{m m}$ & $\boldsymbol{h}_{\mathbf{k} 2}, \mathbf{m m}$ \\
\hline 1 & 25 & $\infty$ \\
\hline 2 & -25 & $\infty$ \\
\hline 3 & 50 & $\infty$ \\
\hline 4 & -50 & $\infty$ \\
\hline 5 & $\infty$ & 300 \\
\hline 6 & $\infty$ & -300 \\
\hline 7 & $\infty$ & $\infty$ \\
\hline
\end{tabular}

\section{TABLE II. Parameters adopted for analysis}

\begin{tabular}{|l|c|}
\hline Feed per blade $f_{\mathrm{z}, \mathrm{mm} / \mathrm{z}}$ & 0,2 \\
\hline Tool diameter $d, \mathrm{~mm}$ & 10 \\
\hline $\begin{array}{l}\text { Radius of the cutting edge contour } r_{\mathrm{n}}, \\
\mathrm{mm}\end{array}$ & 85 \\
\hline Axial infeed $b_{\mathrm{r}}, \mathrm{mm}$ & 4 \\
\hline Material & $\mathrm{AW} 6060$ \\
\hline$K_{\mathrm{tc}}, \mathrm{MPa}$ & 1450 \\
\hline$K_{\mathrm{rc}}, \mathrm{MPa}$ & 280 \\
\hline$K_{\mathrm{ac}}, \mathrm{MPa}$ & -110 \\
\hline$K_{\mathrm{te}}, \mathrm{N} / \mathrm{mm}$ & 21,29 \\
\hline$K_{\mathrm{re}}, \mathrm{N} / \mathrm{mm}$ & 42,5 \\
\hline$K_{\mathrm{ae}}, \mathrm{N} / \mathrm{mm}$ & $-3,1$ \\
\hline
\end{tabular}

\section{Analysis of results}

Figs. 5-11 present graphs of dependences of the cutting force $F_{\mathrm{t}}, F_{\mathrm{r}}, F_{\mathrm{a}}$ for different values of curvature radius $r_{\mathrm{k} 1}, r_{\mathrm{k} 2}$ as a function of the angle of rotation of the tool $\varphi$.

To compare the effect of the radii of curvatures $r_{\mathrm{k} 1}, r_{\mathrm{k} 2}$, the values of the cutting force components obtained by simulating the flat surface machining were first examined (fig. 5).

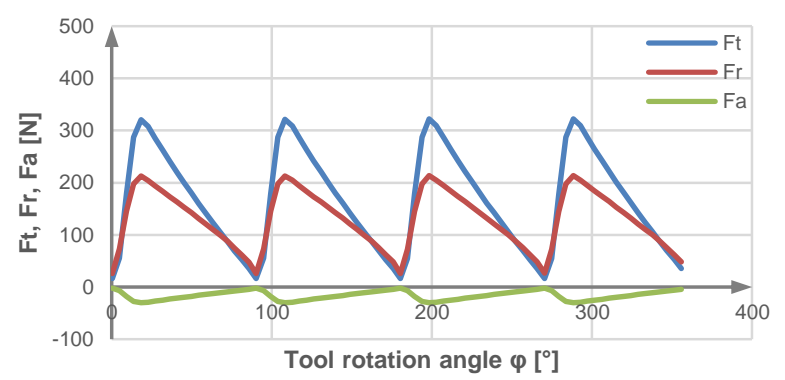

Fig. 5. Course of the components of the cutting force of a flat surface

From the presented waveforms, the tangential component $F_{\mathrm{t}}$ obtained the highest value - about $310 \mathrm{~N}$. The value of the radial component $F_{\mathrm{r}}$ reached approx. $210 \mathrm{~N}$ and the axial component $F_{\mathrm{a}}$ - approximately $30 \mathrm{~N}$.

Subsequently, tests were carried out for a concave surface with a radius of curvature $r_{\mathrm{k} 1}=-25 \mathrm{~mm}$ (fig. 6).

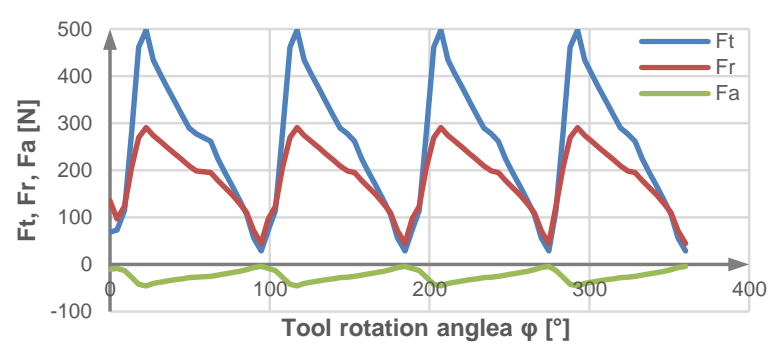

Fig. 6. Course of the cutting force components for the concave surface with curvature $r_{\mathrm{k} 1}=-25 \mathrm{~mm}$

On the basis of the presented courses of the cutting force components, it can be stated that the maximum value of the $F_{\mathrm{t}}$ component is $500 \mathrm{~N}$. In relation to the results obtained during the flat surface machining, an increase of approx. $60 \%$ took place. In the case of the $F_{r}$ component, the maximum value reached $290 \mathrm{~N}$, which is also an increase compared to the results obtained for the flat surface machining by approx. $60 \%$. However, the value of the $F_{a}$ component was a maximum of $45 \mathrm{~N}$, which indicates an increase of approx. $50 \%$ in the flat surface machining.

The test results for the concave surface with the radius of curvature $r_{\mathrm{k} 1}=-50 \mathrm{~mm}$ are shown in fig. 7 . 


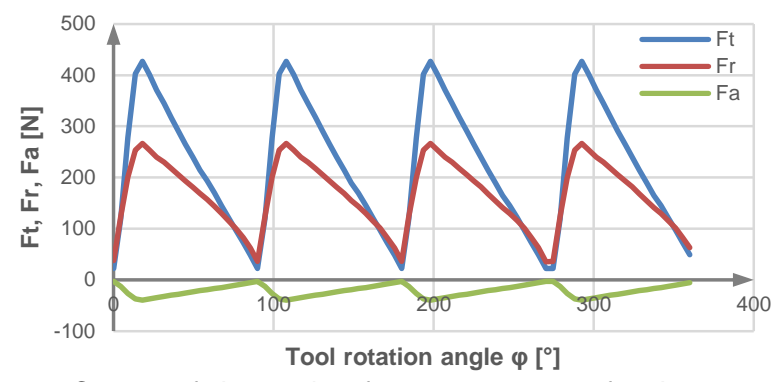

Fig. 7. Course of the cutting force components for the concave surface with curvature $r_{\mathrm{k} 1}=-50 \mathrm{~mm}$

The tangential component was $F_{\mathrm{t}}=426 \mathrm{~N}$, which is a value greater by approx. $38 \%$ in relation to the results obtained for the flat surface. Also, the radial component was greater than the value for a flat surface by approx. $38 \%$ and was $F_{r}=180$ $\mathrm{N}$. The increase of the axial force was about $22 \%$.

In the case of a convex surface with a radius of $r_{1}=+25$ $\mathrm{mm}$, the tangent component was $F_{\mathrm{t}}=292 \mathrm{~N}$, which is a value about $16 \%$ lower compared to a flat surface (fig. 8). The difference in radial components was $5 \%$, while the axial component reached the value $F_{r}=26 \mathrm{~N}$ - about $13 \%$ less than the results obtained for a flat surface.

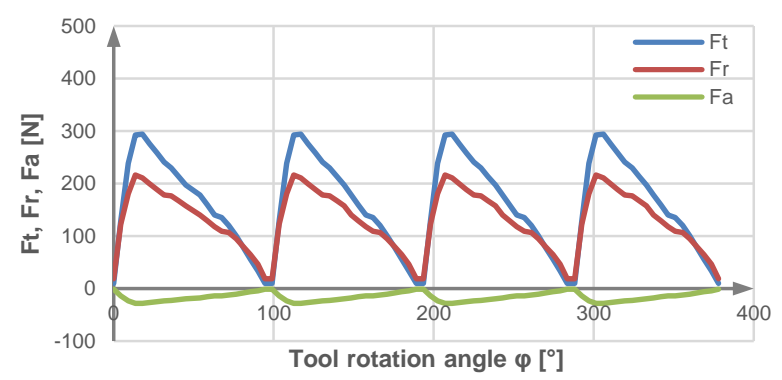

Fig. 8. Course of the cutting force components for a convex surface with curvature $r_{\mathrm{k} 1}=+25 \mathrm{~mm}$

With the increase of the radius of curvature $r_{\mathrm{k} 1}$ to $+50 \mathrm{~mm}$, the components of the forces increase and approach the results obtained for the flat surface (fig. 9).

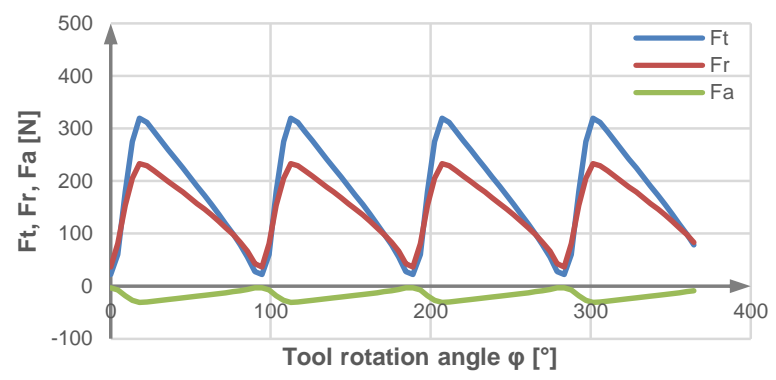

Fig. 9. Course of the cutting force components for the convex surface with curvature $r_{\mathrm{k} 1}=+50 \mathrm{~mm}$

In the case of surfaces with curvature $r_{\mathrm{k} 2}=-300 \mathrm{~mm}$ (fig. 10), the tangent component $F_{\mathrm{t}}=350 \mathrm{~N}$, i.e. by about $10 \%$ more compared to the flat surface. The radial component, on the other hand, reached the value $F_{r}=227 \mathrm{~N}$ - about $5 \%$ more with regard to the machining of a flat surface. On the other hand, the value of the $F_{\mathrm{a}}$ axial component was $32 \mathrm{~N}$. It is important that in the case of machining concave surfaces the values of the minimum values of the courses of the cutting forces are increased.

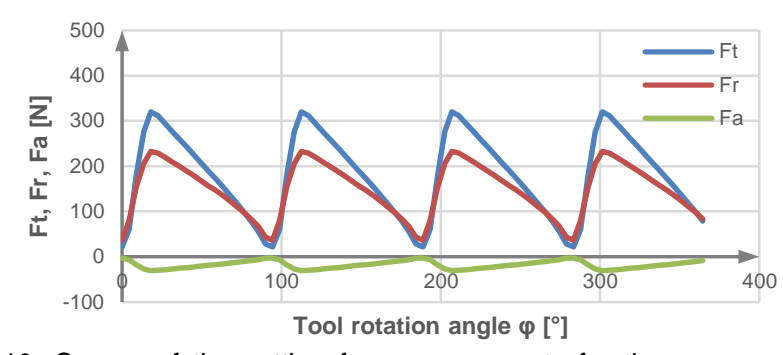

Fig. 10. Course of the cutting force components for the concave surface with curvature $r_{\mathrm{k} 2}=-300 \mathrm{~mm}$

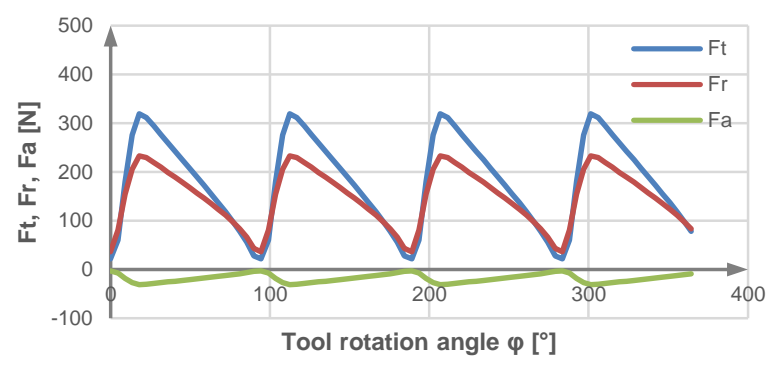

Fig. 11. Course of the cutting force components for the convex surface with curvature $r_{\mathrm{k} 2}=+300 \mathrm{~mm}$

When machining a convex surface with radius $r_{\mathrm{k} 2}=300$ $\mathrm{mm}$, the components of the cutting forces Ft, Fr, Fa do not change significantly (fig. 11). In addition, it can be deduced from the graphs of the course of the individual components of the cutting force that always two blades simultaneously have contact with the machined surface.

\section{Conclusions}

Simulation tests showed a high variability of the cutting force for different radii of curvature of the machined surface. Differences in the values of the cutting force components were up to $60 \%$. This may result in dimensional and shape errors. Therefore, the values of radii of the curvature of the work surface should be taken into account in the design of the technological process of machining with the use of a barrel milling cutter.

\section{REFERENCES}

1. Artetxe E., Urbikai G., Lamikiz A., López-de-Lacalle L.N., González R., Rodal P. „A mechanistic cutting force model for new barrel end mills”. Procedia Engineering. 132 (2015): s. 553-560.

2. Burek J., Żurek P., Sułkowicz P., Żurawski K. „Programowanie procesu pięcioosiowej symultanicznej obróbki frezem baryłkowym w programie HyperMILL". Mechanik. 89, 5-6 (2016): pp. 470-471.

3. Burek J., Żurek P., Żurawski K. „Porównanie chropowatości powierzchni złożonych po obróbce frezem baryłkowym oraz kulistym". Mechanik. 10 (2016).

4. Burek J., Żyłka Ł., Żurek P., Żurawski K., Sałata M. „Badania symulacyjne warstwy skrawanej frezem baryłkowym”. Mechanik. 90, 8-9 (2017): pp. 714-716.

5. Chaves-Jacob J., Poulachon G., Duc E. „Optimal strategy finishing impeller blades using 5-axis machining”. The International Journal of Advanced Manufacturing Technology. 58 (2012): pp. 5731-5830.

6. Ehsan Layegh K., Lazoglu K., Ismail K. „A new identification method of specific cutting coefficients for ball end milling". Procedia CIRP. 14 (2014): s. 182-187.

7. Gorka U., Artetxe E., López de Lacalle, Norberto Lopez de Lacalle $L$. „Numerical simulation of milling forces with barrel-shaped tools considering runout and tool inclination”. Applied Mathematical Modelling. 47 (2017): pp. 619-636.

8. Li T., Chen W., Xu R., Wang D. "Flank milling for blisk with a barrel ball milling cutter". Key Engineering Materials. 407-408 (2009): pp. 202-206. 
9. Tasy D.M., Her M.J., "Accurate 5-axis machining of twisted ruled surfaces". Journal of Manufacturing Science and Engineering. 123, 4 (2001): pp. 731-738.

10. Wang D., Chen W., Li T., Xu R. "Five-axis flank milling of sculptured surface with barrel cutters". Key Engineering Materials. 407-408 (2009): pp. 292-297.

11. Yang Y., Wan M., Zhang W., Ma Y. „Extraction of cutter-workpiece engagement for multi-axis milling”. Materials Science Forum. 770 (2014): pp. 357-360.

Translation of scientific articles, their computer composition and publishing them on the website www.mechanik.media.p by original articles in Polish is a task financed from the funds of the Ministry of Science and Higher Education designated for dissemination of science.

Ministry of Science and Higher Education

Republic of Poland 